Article

\title{
Preventing Mass Atrocities: Ideological Strategies and Interventions
}

\author{
Jonathan Leader Maynard \\ Department of Politics and International Relations, University of Oxford, Oxford, OX1 3UQ, UK; \\ E-Mail: jonathan.leadermaynard@politics.ox.ac.uk
}

Submitted: 15 May 2015 | In Revised Form: 5 August 2015 | Accepted: 7 August 2015 |

Published: 27 October 2015

\begin{abstract}
Both scholars and international actors frequently stress the important role played by anti-civilian ideologies in escalating risks of mass atrocities against civilians. Yet strategies to combat and counter anti-civilian ideologies remain an uncertain and understudied component of atrocity prevention, and scepticism about their efficacy is to be expected. This paper provides a preliminary framework for thinking about strategies and interventions designed to counter the ideological causes of mass atrocities. First, I briefly clarify what existing research seems to suggest the role of ideology in mass atrocities is, and is not. I caution against cruder or overly strong theses about the role ideology plays, but clarify that whilst ideology's actual causal impact is varying and complex, it is also significant. Second, I clarify what ideological interventions and strategies might be reasonably expected to do, and comparatively assess them against more dominant existing prevention tools to show that their preventive potential is sufficiently high to warrant usage. Finally, I provide guidelines on how the effort to formulate ideological strategies and interventions for preventing mass atrocities should best proceed.
\end{abstract}

\section{Keywords}

discourse; genocide; hate speech; human rights; ideology; mass atrocity; prevention

\section{Issue}

This article is part of the special issue "Mass Atrocity Prevention", edited by Professor Karen E. Smith (London School of Economics and Political Science, UK).

(C) 2015 by the author; licensee Cogitatio (Lisbon, Portugal). This article is licensed under a Creative Commons Attribution 4.0 International License (CC BY).

\section{Introduction}

Scholars and international actors have frequently identified ideology as a factor which affects the risk of mass atrocities (Alvarez, 2008; Chalk \& Jonassohn, 1990, p. 37; Gellately \& Kiernan, 2003, p. 375; Malešević, 2006, p. 209; Shaw, 2003, pp. 40-41, 100-123; Straus, 2012a; Valentino, 2004, pp. 71-72). Prominent early-warning or risk assessment models, such as those of Barbara Harff (2003) or the UN Office for the Prevention of Genocide and the Responsibility to Protect (United Nations, 2014), also generally incorporate measures of ideology, or ideologically implicated phenomena like propaganda, hate speech, or extremism, into their core monitoring criteria. If ideology plays a significant causal role in mass atrocities, it should be a logical object of study for mass atrocity prevention. ${ }^{1}$

Yet little such study presently exists. Strategies to combat anti-civilian ideologies (Slim, 2007)-via interventions such as peace broadcasting, empowerment and protection of moderate voices, regulation of ideological producers like the media and political parties, or educational efforts designed to cultivate opposition to violence-are weakly formulated in theory, and rarely attempted in practice. ${ }^{2}$ Whilst the post-Cold War period has seen a considerable increase in military and economic attempts to combat humanitarian crises, a

\footnotetext{
1 For early work, though not orientated around the concept of ideology, see Metzl (1997), Price (2000), Price and Thompson (2002).

2 Such policies are more prevalent in peacebuilding and counter-terrorism, see Bratić (2008) and Gregg (2010).
} 
self-reinforcing inertia holds back ideological strategies. Given the dearth of knowledge about them, such strategies are understandably seen as carrying uncertain prospects of success, and therefore rarely used. In a vicious cycle, this then results in few cases for the empirical research that would improve understanding of their prospects of success and best practices.

This paper makes the case for escaping this vicious cycle, and turning ideological strategies and interventions into key components of mass atrocity prevention. I argue that on comparative analysis ideological strategies and interventions are not inferior to dominant military, economic and diplomatic policies of prevention, if they are conducted with appropriately modest ambitions and sophisticated planning. We need more prevention tools, not fewer (Bellamy, 2011, p. 6). Ideological strategies are unlikely to independently halt a genocide or mass atrocity on their own, but they have the potential to substantially frustrate campaigns of violence and thereby save lives, whilst carrying fewer risks and lower costs than more radical interventions. They ought to be a key element (one of several) in the atrocity prevention toolkit.

I make this argument in three steps. ${ }^{3}$ First, I clarify what existing research seems to suggest the role of ideology in mass atrocities is, and is not. I caution against cruder or overly strong theses about the role ideology plays, but clarify that whilst ideology's actual causal impact is varying and complex, it is also significant. Second, I comparatively assess ideological strategies against conventional prevention tools to show that their preventive potential is sufficiently high to warrant usage. Third, I provide guidelines on how the formulation of ideological strategies and interventions for preventing mass atrocities should best proceed.

My argument here is not that ideological interventions and strategies will assuredly end mass atrocities once and for all. But no existing policy or set of policies meets such a high standard. Prevention remains a somewhat experimental endeavour, and the considerable risks involved are warranted only because the consequences of inaction are so severe. It is therefore crucial to formulate prevention policies with extensive and sober attention to risks and contextual complexities, and with a wide range of potential preventive tools under consideration. The ultimate objective should be to generate a panoply of different ideological strategies and interventions to be made available to policy makers, with guidance on how they should be implemented, their prospects of success, and the conditions when they are and are not advisable.

I also emphasise that whilst my argument here is partly normative-advocating ideological strategies-I

\footnotetext{
${ }^{3}$ For a succinct policy-brief on ideological strategies (of which I was the principal author) see Australian Civil-Military Centre \& Oxford Institute for Ethics, Law and Armed Conflict (2013).
}

do not fully address all relevant normative controversies here. Like all atrocity prevention tools, ideological interventions and strategies can be misused and abused, and carry moral risks, with free speech concerns particularly salient. Such concerns warrant debate, but again, they are not fundamentally deeper or more intractable than those attached to other established prevention policies. They should not stop ideological strategies and interventions from being part of the prevention toolkit.

Throughout this paper, I use ideology to mean $a$ distinctive system of normative and/or purportedly factual ideas, typically shared by members of groups or societies, which shapes their understandings of their political world and guides their political behaviour. This is a self-consciously broad definition, consistent with key trends in the specialist study of ideology (Freeden, 1996; Gerring, 1997; Hamilton, 1987; Jost, 2006; Knight, 2006) as well as much work on political violence and mass atrocities (Alvarez, 2008, pp. 215-220; Sanín \& Wood, 2014, p. 214). It abandons the misleading assumption that ideology always takes the form of highly elaborate theory, immovable convictions, or fanatical dogma. Instead the concept of ideology should be used expansively to grapple with the wide variety of distinctive systems of ideas through which individuals and groups engage in "actual political thinking" (Freeden, 2008, p. 197). ${ }^{4}$ I use ideological strategies to refer to an overall effort to counter the ideological causes of mass atrocities with respect to a particular context, and ideological interventions to refer to the specific tools that may be deployed as part of such a strategy.

\section{How Ideology Catalyses Mass Atrocities}

A key obstacle to considering exactly how ideology catalyses mass violence is the common tendency to confine it to only a narrow range of especially blatant causal roles. Often, both in studies that emphasise ideology's role (Goldhagen, 2010; Kaufman, 2001, 2006) or that express some scepticism (Kalyvas, 2006, pp. 4448; Mueller, 2000; Waller, 2007, pp. 40-53, 102-104, $124,185)$ scholars focus on intergroup hatreds, explicit incitement, exterminationist tendencies, or other overt forms of extremism, and portray "ideological" individuals as highly committed "true believers". Ideologies do sometimes play such roles, and a few participants in mass violence match classic images of the hate-filled fanatic. But confining our attention to such extreme ideological manifestations results in a very narrow lens of focus. It deflects attention from the broader range of causal links between ideology and mass atrocities, and from the more nuanced range of ways in which ac-

\footnotetext{
${ }^{4}$ I shall not focus on conceptual/definitional issues further in this paper, but for clarifications see Leader Maynard (2014, pp. 823-825; 2015, pp. 191-193).
} 
tors can be influenced by ideology (Leader Maynard, 2014).

Close research on perpetrators, like Christopher Browning's (2001) work on Police Battalion 101 or Lee Ann Fujii's $(2008,2009)$ study of Rwandan genocidaires illustrates the wrongness of crude, monocausal explanations cashed out only in terms of ideological fanaticism and ethnic hatred. But they do not show that ideology, understood more broadly, lacked causal power in shaping perpetrator behaviour-and Browning himself explicitly affirms its importance (Browning, 2001, pp. 150-151, 182, 220-221). Ideologies can encourage violence at far weaker or more ambivalent levels of belief than fanaticism, and through mechanisms beside hatred. And whilst total internalisation of an ideology in given individuals is rare, partial internalisation is common, with particular atrocity-justifying beliefs, assumptions, frames or ethics influencing perpetrator behaviour (Leader Maynard, 2015). The exact role ideology plays thus varies across individuals according to different degrees of internalisation, and the presence or absence of other motives connected with selfinterest, opportunism, experience of coercion, conformity to peer pressure, and so forth (Smeulers, 2008). In general, ideological plays a synergistic and often necessary role in tandem with such motives to link them to violence. So fanaticism may be rare. But all mass atrocities nevertheless possess, as Alvarez (2008, p. 215) argues, "an ideological component that is integral to enabling and facilitating the perpetration of this particular form of group violence."

The body of research supporting this claim is extensive. Amongst the direct perpetrators of atrocities, studies like Omar Bartov's (1994) detailed examination of the letters and diaries of Wehrmacht soldiers, Michael Mann's (2000) biographical analysis of fifteen hundred perpetrators, or Yaacov Lozowick's (2000) study of German bureaucrats under the Nazis, emphasise how internalisation of Nazi ideology was important for participation in genocide. So does the testimony (against their self-interest) of former perpetrators and witnesses, in memoirs like those of the Commandant of Auschwitz Rudolf Hoess (1959) or the Bolshevikturned-dissident Lev Kopelev (1977), or in interview data collected by Jean Hatzfield (2005) in Rwanda or Orlando Figes (2002) in the former Soviet Union. At the level of elite policy makers, documentary evidence like that collected in John Arch Getty and Oleg Naumov's (1999) compendium of Soviet government texts from Stalin's terror or Jeremy Noakes and Jeffrey Pridham's (1988) similar volume on Nazi atrocities repeatedly illustrate how ideological justifications shaped the decisions to initiate atrocities. Ideology is also highlighted in numerous comparative case studies. Stuart Kaufman (2001) emphasises the importance of elite decisions to deploy, or refrain from, exclusivist and aggressive symbolic politics that resonate with broader populations in determining whether ethnic atrocities occur. Eric Weitz (2003), Michael Mann (2005) and Scott Straus (2015) all similarly demonstrate how conceptions of states as ethnically pure communities create strong pressures towards what Straus terms "mass categorical violence". And Alex Bellamy (2012b) analyses the role played by recurring justificatory patterns in mass atrocities across cases as wide ranging as the French revolutionary terror, the Armenian genocide, the Boer War, genocide against the Native Americans, Belgian exploitation of the Congo, the Holocaust, Stalin's Great Terror, and a range of Cold War atrocities by capitalist and communist states alike.

Exactly how ideologies causally contribute to violence is complex, however (Leader Maynard, 2014, pp. 825-833). Both the specific ideologies of political actors, and the broader ideological environment in which those actors exist, shape their behaviour. All political practices, violent and non-violent, occur in certain ideological environments: social worlds characterised by distributions of different ideologies amongst the population and the embedding of those ideologies in institutions and discourses. ${ }^{5}$ Such environments are always vitally heterogeneous, but they are nevertheless patterned and analysable. Rather than a chaotic anarchy of disagreement and mutual incomprehension, they have a complex topography defined by certain convergences and divergences in ways of thinking. In these ideological environments, certain things are thinkable and sayable, certain things likely to provoke support from certain groups and opposition from others, certain things likely to be widely believed and others given little credence, certain things comprehensible, resonant, powerful, and fashionable, and certain things ephemeral, turgid, mysterious or dull. Along with the material environment, this ideological environment (plus individuals' own personal ideologies) shapes actors' political behaviour: determining the likely outcomes of certain claims, policies, and events and consequently the costs and benefits political actors perceive as accruing from certain acts. Ideological environments are changeable and constantly changing, in large part through the dissemination of new ideological discourse by influential actors. But as all efforts to change them occur within the existing environment, ideological change occurs by rapid or gradual accretion, building off what has been laid before (Ball, Farr, \& Hanson, 1989, p. 3).

Both overall ideological environments and particular ideologies within those environments can, on bal-

\footnotetext{
${ }^{5}$ These ideological environments are one aspect of the broader "political environments" described by Wolfsfeld (2004, p. 25). They include but are not exhausted by structures of "norms" in the sense widely studied by international relations theorists (Finnemore \& Sikkink, 1998), since ideologies contain more than just normative beliefs and perceptions.
} 
ance, catalyse or restrain mass atrocities (Straus, 2012b, 2015). But ideologies or ideological environments shouldn't be thought of as simply pro- or antiviolence in their totality. All ideologies, and thus all ideological environments, contain a broad amalgam of ideas, some of which are conducive to violence, and some of which problematise it. Possibly barring the strongest forms of pacifism, no ideology contains absolutely no material for the justification of mass violence (Ceadel, 1987). Equally, even a mass murderous ideology like Nazism contained some elements (such as an adulation of discipline and order) that restrained violence in certain times and contexts-contributing, for example, to the early emigration rather than mass killing of Jews, the prohibition of rape in the occupied Eastern territories, and the generally lower level of violence in occupied Western Europe (Bartov, 1994, pp. 60-69; Browning, 2004, Ch. 3; Semelin, 1993, pp. 5-20). Most ideologies and ideological environments possess a greater mix of catalysing and restraining elements than Nazism or Pacifism. Ideologies and ideological environments are thus characterised by an aggregate balance of pressure at particular points of time, and it is this balance between catalysing and restraining elements which is critical (Semelin, 1993, p. 141; Straus, 2015, pp. 34-41).

Difference in this balance of ideological pressure is a key variable in distinguishing contexts where mass atrocities are a real possibility from those where they are unlikely. This is true between cases: Straus (2015) shows how differences in the ideological environments of Rwanda and Sudan, on the one hand, and Senegal, Mali and Côte d'Ivoire on the other, were critical for genocide occurring in the former but not in the latter. But such ideological variation also matters within cases. Vladimir Solonari (2010, p. 193-199) highlights how varying participation in the persecution of Jews in Romania during World War II was shaped by local Christian attitudes: general indifference facilitated violence against Jews, but violence was lower in areas of ideological opposition (see also Semelin, 1993, pp. 139140). David Yanagizawa-Drott's (2014) study of the impact of the RTLM radio station in Rwanda likewise demonstrates that areas with greater saturation of $\mathrm{Hu}$ tu power ideology saw substantially higher violence. And Jacques Semelin (1993) shows how varying levels of resistance to genocide in Nazi occupied Europe similarly rested on the strength of local ideological attitudes opposed to violence against Jews (see also Monroe, 2011).

Importantly, these attitudes did not just matter because they directly encouraged resistance. Knowledge of the ideological inclinations of the local populace shaped decisions by policy makers too: Nazi concerns about, for example, public opinion in Scandinavia encouraged comparatively weak implementation of Holocaust policies in Denmark, Norway and Nazi-allied Fin- land (Semelin, 1993, pp. 132-133, 137-140). By contrast, (correct) expectations of local sympathy for mass violence against Jews in much of Eastern Europe facilitated the choice for radical exterminationist policies in these areas. So the ideological topography of a society influences the topography of violence. ${ }^{6}$ And this topography of violence is analytically and morally important. A more varied topography of violence may not count as a mass atrocity "prevented". But it may mean more areas where dozens, hundreds or thousands of potential victims might be saved.

The specific ideologies espoused by individual actors-whether elite decision-makers, potential direct killers, bureaucratic intermediaries, bystanders, or rescuers and resisters-can catalyse or restrain violence in a wide range of ways. Three cross-cutting distinctions are of particular importance. First, elements of ideologies may actually constitute the sincerely internalised beliefs of members of these various categories, but they may also be used for key instrumental functions, such as mobilising support, politically legitimating actions to others, providing co-ordinating roadmaps for policy, and so forth (see also Sanin and Wood, 2014). Second, ideologies may shape key emotional and evaluative stances, thereby shaping normative beliefs and key value commitments (Atran \& Axelrod, 2008; Sanín \& Wood, 2014, pp. 220-222), but they may also provide or shape key descriptive beliefs about matters of fact (Hochschild, 2001). Indeed the evaluative and descriptive beliefs tend to be heavily interrelated. Hutu power ideology in Rwanda, for example, rested in part on a deep evaluative degradation of the Tutsi and a spread of a genocidal norm permitting mass violence (Fujii, 2004; Melson, 2003). But at least equally critical were descriptive claims that Tutsi really were engaging in calculated conspiratorial activities to undermine the state from within, to assist the invading Rwandan Patriotic Front, and to exterminate the Hutu, claims which seemed plausible in light of the broader ideological environment (Semelin, 2005, pp. 171-174; YanagizawaDrott, 2014, p. 1954). Finally, ideologies may actually motivate action, making atrocities appear desirable, but they also legitimate action, making atrocities appear permissible. Even if many perpetrators of atrocities have rather mundane, self-interested materialist motives-as some scholars suggest (Gerlach, 2010; Mueller, 2000)-ideology may still be necessary to make violence in pursuit of those motives seem legitimate. Clearly, for example, colonialist atrocities against indigenous peoples were heavily motivated by greed. But mass murder which would have been unthinkable against fellow Europeans was rendered easy in the European empires by ideological notions of the low moral

\footnotetext{
${ }^{6}$ It is obviously not the only factor here-levels of control and the nature of local social networks are, for example, also critical, see Semelin (1993), Kalyvas (2006) and Fujii (2008).
} 
status and minimal rights of "natives" (Bellamy, 2012a).

Research on mass atrocities has identified a wealth of different ways in which ideological beliefs justify violence by producing motives and legitimations. I have suggested elsewhere (Leader Maynard 2014, pp. 829833,2015 , pp. 195-212) that most of these can be organised into a framework of six key recurring "justificatory mechanisms". Ideologies tend to catalyse violence by:

i) encouraging dehumanised conceptions of potential victims;

ii) asserting that the victims are guilty of crimes and thus deserve to suffer violence;

iii) constructing dangerous threats to society, or groups within society, and assertively connecting these threats to potential victims;

iv) engaging in the destruction of perceived alternatives to violence, making it seem inevitable or the only option;

v) valorising violence through virtuetalk, where violence is framed as demonstrating praiseworthy character traits like duty, toughness, loyalty, patriotism, etc.; and

vi) identifying future goods or specifying key political objectives which the violence, it is promised, will yield.

These all encourage people to side-line competing ideological restraints on violence, and provide the claims, impressions, semi-conscious attitudes and frameworks of reasoning that can make violence look like the right course of action (see also Chirot and McCauley, 2006, p. 5). The ideologies of key policy makers of atrocities are typically characterised by all these justificatory mechanisms. And they are disseminated via media, educational and political institutions, and social networks-becoming to varying degrees internalised by members of broader groups and societies. Through such ideological dissemination, the ideological environment is thereby altered in ways that raise the likelihood of mass atrocities.

Emphasis of ideology should not involve a denial of other causal factors, and the centrality and blatancy of ideology will vary across cases. Its role is stark in the totalitarian atrocities of Nazi Germany (Bartov, 1994; Koonz, 2003), Stalinist Russia (Arch Getty \& Naumov, 1999; Goldman, 2011), Khmer Rouge Cambodia (Chandler 2000; Hinton, 1998; Jackson, 1989) or Mao's China (Bellamy, 2012b, pp. 237-259). In a wide range of other cases, ideology's role is less obvious but still critical. In the Yugoslavian wars, for example, there is good evidence that many killers were motivated more by loot and the internal dynamics of vicious hooliganistic paramilitary groups than by high nationalism (Mueller, 2000). And the Serbian, Bosnian and Croatian populations were far less penetrated by long-standing ethnic animosities that is commonly suggested (Gagnon, 2004; Malešević, 2006, pp. 168-184). Yet the patterning of violence remained consistent with its underlying ideological rationale in spite of these other motives and mindsets. Nationalist discourses, myths and rumours conducive to violence were heavily disseminated in the late 1980s and early 1990s, with the result that these potential perpetrators and their supporters had internalised ideological conceptions that shaped behaviour, including threatening representations of other groups, perceptions that violence was the only acceptable course, and brutal militarist attitudes, especially amongst the paramilitaries (Cigar, 1995; Semelin, 2003, pp. 358-361). And ideology also filled important instrumental roles, being utilised opportunistically by elites to mobilise support, denounce and castigate moderates, and to co-opt paramilitaries and funnel their violence against other ethnicities (Gagnon, 2004; Gordy, 1999). Cross-case variation thus inheres in the different specific ways ideology exerts causal pressure, and the varying strength of that pressure vis-á-vis other factors. Binary frameworks that merely ask whether ideology "does" or "does not" matter, by contrast, are simply too blunt for both scholarly and practitioner analysis.

\section{The Need for Ideological Prevention}

Even if ideology is a key cause of mass atrocities, it does not necessarily follow that ideological prevention strategies are advisable. International policy makers have often treated the ideological foundations of violence as immutable. The wars in Yugoslavia produced a panoply of such statements, with President Bush describing the conflict as rooted in "age-old animosities [and] century-old feuds", US Acting Secretary of State Lawrence Eagleburger asserting "this war is not rational. There is no rationality at all about ethnic conflict. It is gut, it is hatred; it is not for any set of values or purposes; it just goes on," (Power, 2003, p. 282) and John Major famously stating to the UK Parliament that outside intervention would be futile given the "ancient hatreds" involved (Allcock, 2000, p. 2). Such portrayals are now almost universally rejected in scholarship. But the more nuanced understanding of the role of ideology I have advanced still does not suggest that it is easy to counter ideological catalysts of atrocity. As Benjamin Valentino points out, "influencing the basic structures or attitudes of societies from the outside remains an extraordinarily difficult task...international actors do not yet understand how to build democracies or foster more harmonious relations between groups." (Valentino, 2004, p. 238) Policy makers therefore currently respond to risks of atrocity with a more familiar set of policy tools: military intervention, peacekeepers, economic sanctions, and mediation (and sometimes also international justice mechanisms, and international commissions of inquiry). 
But it is the very familiarity of some of these atrocity prevention tools which is the problem, creating a beguiling impression of a powerful, "hard" toolkit of standard responses which states and the UN Security Council can implement. On close comparative inspection, it is not clear that traditional tools for atrocity prevention are superior to ideological strategies. I assume that all tools of atrocity prevention should be kept available to policy makers, and that multi-method co-ordinated approaches are necessary for success. So in identifying the weaknesses of traditional atrocity prevention tools in this section I am not arguing that they should not be used. But they are not of some different order of viability when compared to ideological strategies. It is therefore problematic, given the mediocre performance of standard tools, that they currently crowd out more innovative approaches (de Waal, Meierhenrich, \& Conley-Zilkic, 2012, p. 18).

\subsection{The Uneven Record of Traditional Prevention Tools}

An uncomfortable reality about research on the traditional tools of atrocity prevention is the rather gloomy picture it paints of all of them. Almost all these tools suffer from "rally round the flag effects", being utilised by local political elites to legitimate their regime and generate national and regional solidarity against outsiders, perversely increasing atrocity perpetrators' power (Krain, 2005, p. 371; Peskin, 2009, pp. 307-309; Smith, 2012, p. 11; Weiss, 1999, p. 502). Evidence on these tools' efficacy, though extant, is extremely uneven, with few clear cut successes. As Alex Bellamy (2010, p. 599) points out, "with only two partial exceptions, once begun, genocidal killing ends in only one of two ways-by perpetrators deciding they have achieved their objectives or with their military defeat" (see also de Waal et al., 2012, pp. 19-21). Of the two exceptions, one (the mass killing of the inhabitants of the Nuba Mountains in Sudan) was stopped by local resistance combined with disagreement amongst policy making perpetrators, the other (mass killings of Bosnians from 1992-1995) was ended by an international political process but with local resistance and military coercion bringing Serbian groups to the table (Bellamy, 2010, p. 599; de Waal et al., 2012, pp. 25-26).

Yet military action, the policy which does appear able to end genocides and mass atrocities, carries huge costs and risks. In most of the cases where military interventions did end atrocities, they came too late in the day to halt much of the killing, and were conducted for self-interested rather than humanitarian reasons. Some contemporary cases could tentatively be called successes-Sierra Leone in 2000, NATO's intervention in Kosovo in 1999, Australian-led intervention in East Timor the same year, and Operation Provide Comfort in Northern Iraq in 1991. But they sit alongside cases with decidedly mixed results, including the 2011 Libya intervention that supported rebel forces but did not prevent a descent into civil war. Traditional military interventions are hugely expensive-as of July 2015 , US military operations against ISIS had cost $\$ 9.4 \mathrm{~m}$ a day, at a total of $\$ 3.2 \mathrm{bn}$ (Shabad, 2015). They also carry heavy costs in human life and political capital, and they destabilise states and regions, themselves threaten civilians, and typically generate a need for long term reconstruction and state-building which the international community has rarely seemed able or willing to meet. When military operations lack UN sanction they may also erode international law, damage relationships between the world's most powerful states, and legitimise unilateral action for more dubious motives (Russia notably invoked the "responsibility to protect" norm during its military intervention in Georgia in 2008). Like peacekeeping (see below) military interventions can also exacerbate mass killing in the short run by creating a range of incentives for armed groups to target civilians more intensely (Hultman, 2010; Krain, 2005; Wood, Kathman, \& Gent, 2012).

There is now an effort to add greater sophistication to military responses. Planners highlight a wide range of options from fairly uncoercive "flexible deterrent" tools-such as security assistance arrangements, force deployment to nearby allies to signal resolve, surveillance and monitoring operations, and so forththrough to direct military interventions of various forms, from targeted "oil spot" or "demilitarised zone" operations through to full scale air and ground campaigns (Sewall, Raymond, \& Chin, 2010, pp. 65-80, 110115). Some such policies may further diplomatic solutions, though they can also interfere with them. More generally, credible threats to ultimately use military action are vital for lending force to preferable first choice measures like sanctions and peacekeepers (Lopez, 2013, pp. 790-791). But these positive advances do not eliminate most of the concerns regarding military action. Many of the softer forms may also simply lack preventive efficacy-Mathew Krain (2005, p. 380) notes that the "only overt military interventions that appear to be effective in reducing the severity of genocides or politicides are those that explicitly challenge the perpetrators of the atrocities".

Peacekeeping and peace enforcement operations avoid some of the costs and risks of more overt military intervention, and fulfil functions vital to atrocity prevention. But evaluative research paints a patchy record of efficacy. A common concern is that peacekeeping missions may in fact exacerbate the risk of violence and mass atrocities in various circumstances. They may incentivise killers to work more quickly to finish ethnic cleansing, can alter the balance of power and thereby increase strategic incentives for civilian targeting, and have ineptly provided "safe havens" which are not adequately protected, and thereby concentrate civilians for perpetrators to target. They can also function as an 
empty bluff in the absence of real political will that, once exposed, encourages further killing and undermines deterrence (Hultman, 2010, p. 30; Krain, 2005, pp. 366-368). Controlling for the fact that peacekeepers are likely to be sent to more violent-prone crises may eliminate the finding that they tend to make things worse (Melander, 2009). And peacekeepers have clearly made a positive impact in certain casesoften through the delivery of humanitarian aid (Weiss, 1999, p. 22). But the statistical impact of peacekeeping on mass killings of civilians remains disputed. The weak capacity of many peacekeeping forces for the sorts of robust action sometimes required to prevent mass atrocities is one reason for their uncertain or erratic efficacy (Burgess, 2011; Tardy, 2011).

Economic sanctions are a third major policy tool used by international actors, but again their record of performance is concerning. Sweeping comprehensive sanctions have been abandoned by international actors in light of extensive evidence on their egregious humanitarian impacts-sanctions on Iraq are estimated to have led to 100,000 to 227,000 excess deaths among young children (Drezner, 2011, pp. 97-98). They also frequently encouraged corruption, including within the UN system. As Thomas Weiss summarises, comprehensive sanctions are a tool which typically "afflicts vulnerable groups, complicates the work of humanitarian agencies, causes long-term damage to the productive capacity of target nations and penalizes neighbours" (Weiss, 1999, p. 500). Instead, international actors now deploy a range of smart or targeted sanctions to pursue political objectives, including atrocity prevention. Targeted sanctions involve a range of itemspecific, country-specific or institution-specific exceptions, and use financial instruments and selective embargos to target elites and bastions of regime support (Lopez, 2013, pp. 774-777; Tostensen \& Bull, 2002; Weiss, 1999, p. 504). But such exceptions weaken the power of sanctions to actually hurt target states and, as Arne Tostensen and Beate Bull (2002, p. 382) put it: "one cannot overlook that they are a form of sanctions 'leakage' and thus undermine the effectiveness of a sanctions regime". Implementing the complex rules of targeted sanctions and preventing evasion by targets is also exceptionally difficult (Drezner, 2011, p. 103; Grebe, 2010; Lopez, 2013, p. 788; Michaelsen, 2010). Political obstacles in the UN Security Council have also been a problem for targeted sanctions, postponing implementation in ways that allow targets to take adaptive measures, and producing watered down sanctions regimes of no meaningful atrocity prevention capacity (Lopez, 2013, 778-779). Such problems led to the heavy modification of a Security Council draft resolution on the violence in Darfur: rather than targeting sanctions against over thirty individuals as originally planned, the final measures targeted just four (Lopez, 2013, 778779). Some sanctions regimes may even worsen atroci- ties. Arms embargoes can freeze existing balances of power and can thereby undermine resistance to state or non-state atrocity perpetrators - this may have occurred in both Yugoslavia and Syria. Dominic Tierney concludes that "much of the impact of UN arms embargoes in civil wars can be summarized as irrelevance or malevolence" (cited in Drezner, 2011, p. 103), and Tostensen and Bull $(2002$, p. 402) similarly conclude that "sanctions experiences generally have been disappointing...the optimism expressed in some academic circles and among decision makers...appears largely unjustified." There are some plausible success stories, such as Libya's 2003 renunciation of its support for terrorism, and abandonment of nuclear and chemical weapons, and the application of pressure on Cote d'Ivoire and Liberia, and on Libya in 2011, though more research is needed to identify evidence of causal impact (Jentleson, 2006; Lopez, 2013, pp. 780-784). A rough success rate of around $33 \%$ for sanctions is commonly asserted in social science research (Hufbauer, Schott, \& Elliot, 2007; Lopez, 2013, p. 788). Again, sanctions are an important atrocity-prevention tool (Lopez, 2015). But they are both unreliable and risky.

Another key tool for atrocity prevention lies in diplomatic and mediation efforts-less controversial and shorn of the potential for egregious material damage involved in military actions and sanctions. Diplomatic efforts are a critical component of every effort to prevent an emerging high risk of conflict or mass atrocities (Welsh, 2015). But they are clearly often insufficient. Kenya in 2007-2008 is often cited as a key example of diplomacy being used to prevent a mass atrocity, but few other clear cases have been suggested in the literature (Sharma, 2015). In light of Kenya, "coercive diplomacy" is frequently touted as providing the more robust mechanism needed to induce potential perpetrators to come to the table. But one major study (not focused on atrocities) suggests it achieves some success in only $32 \%$ of cases, and remains reliant on outside actors credibly promising harder action should the negotiating parties fail to reach a functional agreement (Art, 2003, p. 405).

The addition of international criminal justice tools and UN monitoring and fact-finding missions to the conceptualised atrocity prevention toolkit is welcome, but these tools are also of uncertain efficacy. International criminal justice tools have aided post-violence reconstruction and reconciliation in states, have advanced the development of relevant international law and, through the ICC's complementarity principle, supported domestic legal regimes for preventing violence. But there is not yet any real evidence of a significant deterrent effect, and ICC indictments have clearly created counterproductive rally-round-the-flag effects, most famously in Sudan (Peskin, 2009, pp. 307-309; Smith, 2012, p. 11). Fact-finding missions play a range of important roles, but there is again little evidence for 
the main preventive causal mechanism attributed to them-the "power of witness" - through which being in the glare of the international community's attention is hoped to deter atrocities (Grace \& Bruderlein, 2012, p. 2). Ultimately the power of witness effect rests on consistent and predictable international action to constrain and punish those who are so witnessed, and since that record is at best emergent the weak present deterrent effect is unsurprising (Krain, 2005, pp. 366, 378).

\subsection{How Do Ideological Interventions and Strategies Compare?}

A proper appreciation of the costs, prospects, strengths and weaknesses of the traditional conflict and atrocity prevention tools just surveyed sets the bar that ideological interventions and strategies should be measured against. My central argument is that they meet that bar. They are of a comparable order of feasibility measured against cost and risk, and therefore ought to be a more central component of the atrocity prevention toolkit.

Evaluating the impact of ideological strategies is inherently difficult, but three key sources of empirical research provide a strong starting point for thinking that they can have a positive impact. The first is the extensive work I summarised in section 2 on how ideological catalysts of and restraints on violence can be critical in determining where atrocities (or other forms of mass political violence) do and do not occur and the scale and intensity they take. Yanagizawa-Drott (2014, pp. 1986, 1989-1991) concludes his study of the causal impact of RTLM in Rwanda by estimating that jamming the radio station, as the United Nations Force Commander in Rwanda, Romeo Dallaire, requested, might have cost around \$4 million and saved upwards of 50,000 lives, as well as reducing long-term damage to human capital formation and political stability. The number of lives saved might fall according to how the regime substituted for the loss of radio capability, but would remain substantial. The most helpful research on ideological causes compares contrasting cases. As noted above, in his extensive comparative study of genocides in Sudan and Rwanda with non-genocides in Côte d'Ivoire, Mali and Senegal, Straus (2015, p. x) finds that "to explain variation-to explain why countries with similar crises experience different outcomes-the role of ideology is essential." Gadi Wolfsfeld's (2004) study of the role of media in peace negotiations highlights the contrast between the generally damaging role of the Hebrew press in the Oslo peace process, and the broadly supportive role media played in Northern Ireland regarding the 1998 Good Friday agreement. Wolfsfeld roots the contrast partly in differences in media norms-one target of ideological interventions and strategies. Kurspahićs (2003) study of the critical catalytic role played by the media in the Yugoslavian Wars and their post-conflict environment charts the general failure of outside intervention. But Kurspahić roots this failure in specific errors of policy, highlights what could and should have be achieved with superior planning and implementation, and emphasises the need for what I am terming ideological interventions.

Two forms of ideological intervention are already widely attempted: regulation of the media environment by international interveners during and after conflict so as to constrain ideological dissemination (as Kurspahić's book highlights), and civil society interventions focused on peace building, peace broadcasting and peace education to promote ideological restraints on violence. The second main source of empirical research on ideological strategies and interventions comes in a small number of dedicated evaluations of such efforts. Paul Collier's and Pedro C. Vicente's (2013) quantitative study of the impacts of ActionAid International Nigeria's (AAIN) experimental intervention against political violence in the Nigerian elections in 2007 is the most rigorous empirical examination of such an ideological campaign thus far. The AAIN's two week campaign, in collaboration with local NGOs, aimed to delegitimise violent intimidation, give individuals a sense of political empowerment, and promote collective action to resist violence. The organisers distributed 18,000 units of campaign materials (T-Shirts, caps, hijabs, leaflets, posters and stickers), and held roadshows, theatre events and town meetings in locations across Nigeria (Collier \& Vicente, 2013, pp. F332335). Collier and Vicente's experimental study of the campaign involved a baseline survey prior to the intervention, and comparison of its effects in 12 enumeration areas visited by AAIN campaigners with 12 control areas that were not (Collier \& Vicente, 2013, pp. F335337). This "found clear and statistically significant effects of the campaign on diminishing perceptions of political violence and increasing empowerment of the population against political violence" (Collier \& Vicente, 2013, p. F344). Even more importantly, the campaign reduced the actual likelihood of violence by $47 \%$ in the areas targeted (Collier \& Vicente, 2013, pp. F350-351).

No other campaign against violence has been so thoroughly studied, but some other research projects exist. A study by Elizabeth Levy Paluck and Donald P. Green of counterviolence radio interventions in Rwanda found that whilst the programmes might not have affected the deep convictions of listeners, they substantially promoted expressions of dissent, perceptions of social norms, and methods of dispute resolution in ways conducive to non-violence (Paluck, 2009; Paluck \& Green, 2009). An edited volume by Monroe E. Price and Mark Thompson (2002) includes five case studies of broadcast media during and after violent conflict. 
These highlight the mixed record of ideological interventions and point to numerous improvements in future efforts. But they do find benefits in international efforts in Cambodia, Bosnia and East Timor-though more in post-conflict recovery than immediate prevention.

Finally, a wider volume of evidence comes from independent assessments of the activities of civil society projects by groups like Search for Common Ground, Fondation Hirondelle, Radio La Benevolencija, PeaceTech Lab and Studio ljambo. In 2008, Vladimir Bratić produced a list of around 40 projects in 18 countries that could broadly be characterised as peace broadcasting or peace education, mainly run by such civil society actors (Bratić, 2008, p. 495). Such projects are regularly subject to evaluative assessments, though these understandably vary in their scientific rigour (for one extensive collection made available by Search for Common Ground see http://dmeforpeace.org/learn/ learn-type/evaluation-reports). Since it is difficult to conduct an ideological intervention without having any positive impacts, the challenge for future empirical research is to a) differentiate really significant and costeffective impacts reported in these assessments from admirable but relatively inefficient ones, and b) to trace whether evidence of attitude changes and a greater sense of security, empowerment, and pacific inclinations amongst those subject to such programmes translates into lower violence in the long-run. Still, such assessments consistently emphasise the impact of campaigns in affecting attitudes towards violence, empowering resistance, and educating populations (for two notable examples of specific reports on impact see Kogen, 2013; Search for Common Ground, 2012).

So despite the need for more research, this threefold evidence base is encouraging, especially measured against the comparatively low costs and risks of ideological strategies relative to most traditional tools of conflict and atrocity prevention. As Edward R. Girardet (cited in Price \& Thompson, 2002, p. viii) writes: "Governments, international organisations, and humanitarian agencies...are often willing to spend hundreds of millions of dollars on humanitarian or peacekeeping operations, but are reluctant to allocate sufficient funding to ensure that people are properly and accurately informed. Normally, this does not take a great deal of money." Ideological efforts to spread accurate information and foster negative attitudes towards violence ought to be deployed more widely. We should not downplay the risks. Getting involved, directly or indirectly, in the ideological battles of a society carries symbolic and physical dangers to those who do so. And from the more macro perspective of international prevention policy, many ideological interventions create a tension with long-standing commitments to neutrality embedded in the United Nations system. It is increasingly recognised, however, that this is an operating principle which most atrocity-prevention efforts problematise (Bellamy, 2011, p. 1). Comparatively low costs and risks, and prospects for a positive impact, require preventive actors to devote more attention to ideological strategies.

\section{Designing Ideological Strategies in Atrocity Prevention}

In this final section, I provide guidelines on how ideological strategies could be formulated by relevant preventive actors. I consider, in turn: 1) what the feasible objectives of ideological strategies are; 2) who the relevant preventive actors might be, and how different sorts of actors should interact; 3 ) what sorts of ideological interventions these actors might deploy; and 4) what key principles should be followed in order to make ideological prevention strategies effective.

\subsection{Objectives}

To be successful, the proper aim of ideological interventions and strategies in atrocity prevention must be clearly conceptualised. Such campaigns cannot just import an external intervener's own notions and norms straight into the target society, nor radically transform its complex, culturally distinct ideological landscape. Instead, feasible ideological strategies aim to erode the general pervasiveness and strength of ideological justifications of atrocity and bolster specific ideological restraints on violence against civilians. Such strategies should target policymaking elites, potential direct perpetrators of violence, and broader society and its ideological environment (including major media organisations). Varying attitudes towards violence amongst all of these groups affect the constellation of macro, meso and micro level decision-making processes that lead to atrocities either occurring or being averted (Straus, 2015, pp. 41-51).

Preventive actors must recognise that the most committed "true believers" in anti-civilian ideologies will typically remain resolute in pressing for violent action. The decisions of these sorts of individuals are better targeted by "harder" preventive tools that alter the costs and benefits they care about, if possible. But the fact that most perpetrators of atrocities are not such true-believers is critical for the reasonable prospects of ideological strategies. This is especially true amongst the broader public, and this is where most existing ideological efforts have focused. But even elites and potential perpetrating organisations are ideologically heterogeneous, and will contain individuals with varying degrees of support, ambivalence, and reluctance towards violence. Efforts (especially by local actors) should therefore also focus "upwards" at elites, since the ideological standpoint of the elites is often the most crucial factor in determining whether violence 
occurs or not (Straus, 2015; Valentino, 2004). Outside actors might, for example, be able to share intelligence with elite policy makers that reduces their perceptions of other groups as threatening, reducing the pressure for atrocities.

So effective ideological strategies do not assume it is possible to convince everyone or initiate mass "conversions" in attitudes towards violence. Instead prevention efforts should contest the ideological and information monopolies which convince relatively ordinary people that violence may be a necessary course, inject doubts and reluctance into mass sentiment, and weaken the popular pressures for discriminatory nationalist, religious or ethnic demagoguery. The realistic aim is to thereby shift the balance of ideological pressures-amongst elites, potential perpetrators, and broader publics-in ways that create obstacles for violence. Since atrocities occur as the result of a complex intersection of causal forces, ideological strategies may not "prevent" an atrocity. But they can encourage opposition, non-implementation, and rescue; hold open opportunities for alternative nonviolent courses; and result in considerably more limited campaigns of violence, saving large numbers of lives. Just as importantly, ideological strategies synergistically support other preventive actions-by delegitimising those who advance campaigns of violence and weakening the forces they are able to mobilise around them. Ideological strategies should also strengthen the social fabric for post-violence reconstruction and reconciliation, and they may indirectly serve broader conflict prevention and counter-terrorism objectives.

\subsection{Actors}

Ideological prevention can be conducted by a range of actors: the United Nations, regional organisations, external states, international or local non-governmental organisations, or even the governments of at-risk societies themselves. But for all ideological strategies, cultural and context sensitivity and a primary reliance on local authorities, movements, organisations and voices for most of the "front-line" ideological work is critical. As Thompson and Price (2003, p. 195) remark (regarding media development, but the point should be a guiding principle for most ideological interventions) efforts are "best designed and implemented by nongovernmental actors-professionals and activists-with IGOs and governments lending assistance as required."

This is both normatively important, but also a practical requirement for success. In most societies, external actors, organisations and states have far lower credibility, authority and ideological influence than local actors, and lack the expertise local actors have in navigating their contextually rich ideological landscape (see also Gregg, 2010, p. 293). The exception might be particularly respected individuals with international reach. The British and US governments are not likely, for example, to have significant ideological influence over potential perpetrators of ISIS atrocities. But Dr. Muhammad Tahir-ul-Qadri, the world respected Islamic scholar who published the first authoritative fatwa against terrorism and suicide bombing in 2010, might. $^{7}$ Non-governmental organisations, national or transnational, are also potentially powerful. Patrice McMahon (2007) highlights the role of such organisations in the avoidance of ethnic violence in Eastern Europe, and they may also be vital for mobilising action by external actors, when needed, to deter or intervene to prevent violence, as Geoffrey Robinson (2010) shows regarding East Timor in 1999. External actors are, however, needed to bring important financial, technological and educative resources and to provide expertise and coordination. A major expansion in such support by the world's most powerful states and leading international organisations will be an important first move in stepping up ideological prevention efforts. There are also, as I discuss below, particular sorts of intervention that external actors are best placed to conduct.

So an effective overall strategy of prevention vitally rests on cross-scale mobilisation, co-operation and coordination. Christian Gerlach (2010) has influentially highlighted how extremely violent practices typically rest on the mobilisation of coalitions of actors with interests in violence. In parallel, the only effective way to generate powerful practices of counterviolence is to mobilise coalitions of the many international, regional, national and sub-national forces with interests in preventing atrocities. This is particularly important in light of the trade-offs that exist between different desirable aspects of ideological interventions, such as impartiality. More impartial strategies (like providing reliable sources of basic information, propagating awareness of legal commitments and international norms, or disseminating public calls for intergroup dialogue) have the advantage of maintaining actors' credibility amongst multiple target audiences, but may be of weak force in countering the really pernicious justifications of violence. The reverse is true of more committed campaigning, and the loss of impartiality involved could be damaging to other prevention tools or discrediting to the local actors one is seeking to support (Babbitt, 2012, pp. 375-384). Balancing such trade-offs is easier when actors can create a co-ordinated division of labour between different sorts of stakeholders: the United Nations may be well placed to fill more impartial functions, whilst concerned external states or regional organisations such as the African Union, OSCE, Arab

\footnotetext{
7 Qadri has also recently published an Islamic Curriculum on Peace and Counter-Terrorism through his non-governmental organisation Minhaj-ul-Quran, see http://www.minhajpubli cations.com/latest-books-peace-deradicalisation-counterterrorism
} 
League or European Union may provide key resources and capacity to local actors, who themselves actually take on the more explicit campaigning.

\subsection{Interventions}

Specific ideological interventions can be schematised according to two vital dimensions-systemic vs targeted, and coercive vs persuasive. The former distinction tracks whether the intervention/strategy is a long run campaign to change the ideological environment in a state that simply carries a considerable background risk of future violence/atrocity, or a reactive, short-run intervention to counter an escalating risk of imminent atrocities (Reike, Sharma, \& Welsh, 2015). The second distinction captures whether the intervention is an attempt to consensually change attitudes and beliefs, or a forcible action, usually aimed at disabling the production and dissemination of anti-civilian ideologies (Leader Maynard, 2015, pp. 218-224). Both distinctions are continua, but simplifying them dichotomously produces an efficient summary (not exhaustive) of major ideological interventions and strategies, as in Table 1:

Table 1. Major forms of ideological intervention.

\begin{tabular}{lll}
\hline & Persuasive & Coercive \\
\hline Systemic & - Peace broadcasting & - Criminalisation \\
& - Peace education & - Chartering \\
& - Pluralisation & \\
Targeted & - Peace broadcasting & - Jamming \\
& - Empowering resisters & - Destruction \\
\hline
\end{tabular}

At the systemic-persuasive level are the existing efforts of local and transnational civil society organisations to engage in peace broadcasting (the propagation of ideas through major media) and peace education (participatory pedagogic and training practices). A third systemic-persuasive ideological intervention, pluralisation involves seeking to generate greater access to a wider range of media (in the broadest sense) in recognition of the particular danger of ideological monopolies. For example, pluralisation might involve encouraging more penetration by international media organisations such as the BBC, Al Jazeera, and CNN, all generally rated as highly trustworthy by citizens which have access to them in states across the world (Geniets, 2011). These cannot be captured by local anti-civilian ideologies, and undermine the monopolies within which those ideologies can come to appear like "common sense". Increasing access to online social media is also important, although as well as providing a means for opening up the ideological monopolies of closed or partially closed societies, these can facilitate radicalisation within online ideological "echo chambers" (Schissler, 2014; Thompson, 2011). Less obvious methods include international educational and vocational exchanges, or publishing internationally collaborative school textbooks.
Coercive-systemic measures include the establishment of legal regimes that obstruct the production and dissemination of anti-civilian ideology. Sometimes this may involve criminalisation of incitement or extreme forms of dangerous speech, and the provision of easily accessible avenues for civil actions against the dissemination of slander and libellous rumours and claims. Equally, measures I shall term chartering, in which media organisations, political parties, intellectual bodies or other relevant ideological producers commit to legally enforced standards for reporting, political campaigning, or education offer a somewhat less coercive measure that can still be given legal teeth.

Systemic ideological interventions are generally more powerful than targeted interventions. Ideological change is a very real phenomenon, but generally takes time. And in the crisis environments where risks of atrocity sharply escalate, radicalizing appeals have various advantages over calls for moderation and restraint. Nevertheless, targeted ideological interventions exist and may be vital in generating obstacles to violence and reducing participation and death rates. The most important targeted-persuasive ideological intervention is likely to be empowering resisters. Perpetrators of atrocities typically identify and even compile lists of opponents and moderates, whether individuals or groups, who are often early targets of violence. Preventive actors should also have an up-to-date awareness of such potential resisters of violence-religious leaders, political figures, intellectuals, and the leading members of major social movements-and can offer them protection, asylum, co-ordination, resources to propagate ideological restraints on violence, or other forms of support. Peace broadcasting also remains relevant at this level (whereas peace education is generally only feasible at the systemic level). Saturating a society with moderate voices and ideological restraints on violence could fragment violent campaigns, encouraging desertion and non-participation.

The most controversial, but better practiced, forms of targeted intervention are coercive-the jamming of ideological dissemination and disabling, capture or destruction of relevant hardware (Price, 2000). By jamming, I denote all coercive methods that block dissemination without causing lasting human or physical damage. This may include shutting down websites, disabling SMS networks, banning or breaking up extremist rallies or even detaining radical preachers and inciters, as well as the blocking of radio and television transmissions. Destruction, by contrast, involves the infliction of lasting damage or harm, ideally only infrastructural but often also human. Radio and television installations that cannot be feasibly jammed might be physically disabled or destroyed, or the most influential and extreme articulators of anti-civilian ideologies can even be killed. But in most circumstances, destruction will prove highly counterproductive to atrocity-prevention 
efforts. Such acts fuel the narratives of atrocityjustifiers, delegitimise preventive actors, and fragment the coalitions of such actors necessary for effective prevention, by placing local partners in a bind in deciding whether to support an attack that may have killed their co-nationals or to denounce their international allies. Such actions are, however, part of the conceptual space of ideological intervention tools, and fuller normative investigation than I can provide here is necessary to conclude when if ever such actions are justified. Jamming is more likely to be of use to preventive actors. But the international community still lacks clear guidelines on when jamming might be justified and appropriate in atrocity-justification efforts. Again, all targeted-coercive measures (and most systemic-coercive measures) also raise free speech concerns that require consideration.

\subsection{Making Ideological Strategies Effective}

Nevertheless, such free speech concerns are not simply overriding. It is critical, if mass atrocities are to be prevented, to resist the alluring metaphor of a 'marketplace of ideas', where the sufficiently free circulation of ideas is assumed to create the best chances for truth and morality to thrive. This misguided metaphor, and an accompanying faith in the auto-corrective properties of freer and freer speech, remains problematically influential amongst many state and non-state actors involved in violent contexts (Allen \& Stremlau, 2005, pp. 3-10). Yet it lacks empirical foundation, and fundamentally fails to appreciate how the production and consumption of ideology actually works. Real world societies, especially those at most risk of atrocities, do not match idealised images of truth-seeking public communicative spaces. As a now extensive body of research in psychology, sociology and communication studies emphasises, ordinary consumers of ideology are not strongly motivated by how well-grounded claims are in real evidence, and ideological producers frequently have strong commercial and political agendas driving what they produce (see Boudon, 1989; Cohen, 2001; Edelman, 1977; Glaeser, 2005; Jost, Federico, \& Napier, 2013; McChesney, 2004; Varki \& Brower, 2013). These non-epistemic motives of both producers and consumers often give them huge incentives to articulate and believe in utterly false or dangerous ideas-as the unyielding resilience of many political myths in the freest media environments demonstrates (IPSOS MORI, 2014). Ideological producers have become extremely sophisticated at packaging even the most absurd claims so as to seem reasonable and compelling. And consumers of ideology rarely cross-check facts, rarely shop around for alternatives to their traditional sources of information, are often religiously or politically committed to key "epistemic authorities", and often lack the capacity to check up on many claims.
Consequently, both mainstream news media and social media online have willingly justified, supported, denied or covered up mass atrocities, notably in Nazi Germany and Yugoslavia (Allen \& Stremlau, 2005, p. 2; Kurspahić, 2003; Straus, 2015, p. 48; see also Schissler, 2014). As Wolfsfeld (2004, pp. 15-23) points out, free media are especially likely to distort reality in conflictprone and peace-building contexts, due to misalignment between the incentive structures of news media and the requirements of a peace process. "Peace is most likely to develop within a calm environment," Wolfsfeld argues, "and the media have an obsessive interest in threats and violence. Peace building is a complex process and the news media deal with simple events. Progress towards peace requires at least a minimal understanding of the needs of the other side, but the news media reinforce ethnocentrism and hostility towards adversaries." (Wolfsfeld, 2004, p. 2) The "epistemic tyranny" of closed societies may be the biggest obstacle to a well-informed and morally reflective public, but an unregulated "epistemic anarchy", where a panoply of agenda-driven organisations and groups are able to propagate entirely unfounded claims, and where citizens lack reliable reference points and the skills and resources to interrogate ideology, is not much better.

The solution has two components that should be embedded in ideological strategies to prevent atrocities. First, an epistemic rule of law - a regulated media and political environment that protects free speech rights but also sets standards for the assertion of facts under the authority of "news", and commits major ideological producers to ethical best practices (Bratić, 2008, p. 501). Where media function effectively to promote rights, democracy, and non-violence, it has not been due to the stripping away of all regulation, but due to an effective balance of standards and checks (though worryingly ones that, in many wealthy states, have been progressively dismantled, see McChesney, 2004). And these should be supported by responsible media norms (Wolfsfeld, 2004, pp. 38-43). This makes it much harder for dangerous local or national ideological monopolies to emerge.

Second, a concerted effort by preventive actors to actually participate in that ideological environment in a strategic and locally rooted fashion is vital. There is no truly "neutral" interaction with the ideological environments in which mass atrocities are a significant risk, and to refuse to engage systematically in bolstering forces that uphold rights and call for non-violence is simply to retire from the field of battle and allow other ideological protagonists to dominate social space. All atrocities, though typically witnessed by the world as a sudden event, are rooted in longer term processes of social radicalisation involving ideological campaigning. The same must be true of ideological efforts to prevent atrocities (Bratić, 2008, pp. 500-501). These cannot rely 
on idealised assumptions of perfectly rational actors, who will be won over as soon as they presented with the "best" arguments. Instead ideological strategies must be based on realistic theories of political thinking and persuasion rooted in leading psychological and sociological research (Della Vigna \& Gentzkow, 2010; Gardner, 2006; Jost \& Major, 2001). The non-epistemic motives behind belief formation need to be engaged with, and strategies should draw on the expertise of the communications specialists, media strategists, public relations industries, and political campaigners who are best practised at ideological battles in the real world.

As noted, ideological strategies need to erode justifications of atrocities and embed ideological restraints. My identification of six justificatory mechanisms for atrocities is intended to highlight the diversity of pathways through which atrocities can come to look permissible or even desirable, and consequently highlight how a broad range of restraining responses are required. Theorists of atrocity prevention have already identified some of the powerful pacific norms that should be generated: Alex Bellamy (2012a, p. 180) proposes "universalism", Hugo Slim (2007, p. 277) "humanization" and David J. Simon (2012, p. 6) "humanism" and "non-divisionism". These are well chosen, since dehumanisation, moral exclusion and the portrayal of some social groups as fundamentally lacking legitimate membership in the state are critical foundations for the justification of violence (Alvarez, 2008; Leader Maynard, 2015, pp. 195-199; Opotow, 1990; Straus, 2015). But such norms are also insufficient-they block some paths of justification for atrocities but leave others open (for example, the presentation of violence as virtuous and heroic, or the denial of alternatives to violence). So we need to flesh out these concepts into a better ideological map for counterviolence. Existing research suggests six main overlapping ideological restraints on atrocities that provide a starting point for thinking about more comprehensive future efforts.

First, as Bellamy and Simon identify, the fragmenting of societies into divided groups is key to mass violence. Conversely, appeals to inclusive unity at the national or communal level, which do not cast some members as outsiders, have been effective in resisting violence. Straus (2015) finds that more inclusive founding narratives were critical to non-occurrences of genocides in Africa, and Susan Benesch (2014) identifies the proliferation of inclusive discourses surrounding the build-up to the relatively peaceful 2013 elections in Kenya as a potentially important pacific force. Second, as human rights norms have spread they have created fundamental and well-researched challenges to intergroup discrimination and state-led violence (RisseKappen, Ropp, \& Sikkink, 1999; Sikkink, 2011). Third, the ideological embedding and institutionalisation of civilian immunity has been critical to changing military practices by many world states-resulting in a notable reduction, though not elimination, of war time atrocities (Bellamy, 2012b, pp. 220-222, 300-348). Fourth, just as violence can be valorised and portrayed as virtuous, so it can be subject to devalorisation by peace messages that exhort virtues of non-violence, and disparage violence as irresponsible, disruptive and hooliganistic (Benesch, 2014). Fifth, violence is much less likely if key actors, groups and broader populations can be convinced of its inefficacy, and in particular, the risk it poses to critical social objectives like economic development and political stability. Finally, deeper rejections of violence as in pacifist or pacificist doctrines (Ceadel, 1987), and the promotion of social change through nonviolent methods like civil disobedience and peaceful protest can massively alter the way in which societies respond to those who call for violence-as in the AAIN campaign reported on by Collier and Vicente (2013).

This is not an exhaustive list. Credibility attacks on those calling for violence, highlighting the crimes with which they have been associated, or otherwise undermining their epistemic and normative authority, may also, for example, be effective. But these six restraints provide a starting point for thinking about the content of ideological preventive action.

Like all prevention, ideological interventions and strategies to prevent mass atrocities rest crucially on will-although they are not as demanding in this respect as some other tools. But as Richard Caplan (2011, p. 131) points out, a major determinant of the will to prevent is the capacity to prevent. Actors will show more will to deploy ideological strategies if these have been well prepared and the necessary practical tools are in place. States, organisations and civil society actors thus need to continue to develop the international counterviolence architecture needed for ideological strategies of prevention: the institutions, professional networks, ground-level operations, funding arrangements, epistemic communities and hardware necessary for both strategic and targeted, and coercive and persuasive, preventive action. Such an architecture is already partially developed with respect to peacebuilding and conflict prevention (and also the rather different field of military PSYOP practices) but needs to be extended to mass atrocities. One important and easy advance, already underway, is to insert an "atrocityprevention lens" (Bellamy, 2011, 2015) into existing practices and structures. And an immediate step for preventive actors is to make sure that such an atrocityprevention lens includes attention to ideological strategies in those organisations with explicit prevention mandates: United Nations agencies, regional actors committed to prevention like the African Union and ECOWAS, and relevant state institutions. But greater capacity-building is also needed-of both hardware (material resources, institutional capacity, volunteers and organisations) and software (educational materials, training, knowledge and imagery). 


\section{Conclusion}

In this article, I have argued that ideology plays a critical but complex role in shaping the probabilities of mass atrocities, and the extent and pattern of violence where atrocities do occur. Ideological fanatics are relatively rare, but more partial, selective, ambivalent, or latent forms of ideological internalisation allow anticivilian ideologies to alter the behaviour of large numbers of ordinary people. Variation in ideological attitudes and beliefs is therefore one key factor explaining inter-case and intra-case variation in violence. For this reason, greater planning and implementation of ideological strategies to prevent mass atrocities is urgently needed. On comparison with other prevention tools, ideological strategies are not fanciful or impractical relative to their costs and risks. They are unlikely to lead to wholesale conversions of the true believers in anti-civilian ideologies. But they can erode the broader appeal of those ideologies, bolster the sorts of ideological restraints that discourage participation in campaigns of violence, and alter the balance of ideological pressures on both elite policy makers and ordinary citizens.

This paper provides initial guidelines for thinking about the range of available ideological interventions, and how they might best be used as part of broader synergistic applications of multiple prevention tools. Both actors with explicit atrocity-prevention mandates and those who are stakeholders in any high risk setting-be they citizens, local organisations, transnational organisations, governments, neighbouring states, regional organisations or international bodies-can and should deploy ideological strategies. But ideological efforts to prevent mass atrocities remain at their earliest stages: more research is needed. Atrocities by transnational non-state organisations like ISIS, which draw on a narrow slice of radicalised supporters from across the globe rather than broader support within an established society, present particular challenges. Research on terrorist radicalisation and counter-radicalisation needs to be brought into work on ideology and atrocities more generally if we are to advance thinking on how to prevent anti-civilian violence by terroristic, criminal, paramilitary and other non-state actors (Horgan \& Braddock, 2010; McCauley \& Moskalenko, 2008).

Nevertheless, persisting intellectual and practical challenges are intrinsic to the life-cycle of prevention tools. More established methods, especially military operations and economic sanctions, went through many extremely costly failures before it really became feasible to think that they might be used with good prospects for success. Refining ideological interventions and strategies will similarly take time, involving failures and only partial successes. But that learning process promises to be less costly than it is for most other tools. And it may ultimate provide a powerful, inspiring, and non-violent component of a functional atrocity prevention toolkit.

\section{Acknowledgments}

I owe thanks to Serena Sharma and Jennifer Welsh for employing me as a research assistant on a short project in 2013, during which I conducted some of the research on preventive tools referenced in section 3 of this paper, as well as for their broader support for my work on atrocity prevention over the last three years. My thanks also to Susan Benesch, Scott Straus and Elisabeth Jean Wood for numerous points of advice and intellectual inspiration regarding the research underpinning this paper, and to Theo Dolan for guiding me to existing research on the evaluation of peace broadcasting efforts. This paper was largely written whilst I was a Junior Research Fellow at New College, University of Oxford, to whom I am grateful for both academic and financial support.

\section{Conflict of Interests}

The author declares no conflict of interests.

\section{References}

Allcock, J. B. (2000). Explaining Yugoslavia, London: C. Hurst \& Co.

Allen, T., \& Stremlau, N. (2005). Media policy, peace and state reconstruction (Crisis States Discussion Paper). London: LSE Crisis States Development Research Centre.

Alvarez, A. (2008). Destructive beliefs: Genocide and the role of ideology. In A. Smeulers \& R. Haveman (Eds.), Supranational criminology: Towards a criminology of international crimes. Antwerpen: Intersentia.

Arch Getty, J., \& Naumov, O. V. (1999). The road to terror: Stalin and the self-destruction of the Bolsheviks, 1932-1939. New Haven: Yale University Press.

Art, R. J. (2003). Coercive diplomacy: What do we know? In R. J. Art \& P. M. Cronin (Eds.), The United States and coercive diplomacy. Washington, DC: United States Institute of Peace.

Atran, S., \& Axelrod, R. (2008). Reframing sacred values. Negotiation Journal, 24(3), 221-246.

Australian Civil-Military Centre, \& Oxford Institute for Ethics, Law and Armed Conflict. (2013). Countering ideologies that justify mass atrocities (The prevention toolbox: systematising policy tools for the prevention of mass atrocities). Retrieved from https://www.acmc.gov.au/wpcontent/uploads/2014/09/4-The-PreventionToolbox-Countering-Ideologies.pdf

Babbitt, E. F. (2012). Preventive diplomacy by intergovernmental organization. International Negotiation, 17, 349-388.

Ball, T., Farr, J., \& Hanson, R. L. (Eds.) (1989). Political 
innovation and conceptual change. Cambridge: Cambridge University Press.

Bartov, O. (1994). Hitler's army: Soldiers, Nazis and war in the Third Reich. Oxford: Oxford Paperbacks.

Bellamy, A. J. (2010). Military intervention. In D. Bloxham \& A. D. Moses (Eds.), The Oxford handbook of genocide studies. Oxford: Oxford University Press.

Bellamy, A. J. (2011). Mass atrocities and armed conflict: Links, distinctions, and implications for the responsibility to prevent (Stanley Foundation Policy Analysis Brief). Muscatine, IA: Stanley Foundation.

Bellamy, A. J. (2012a). Mass killing and the politics of legitimacy: Empire and the ideology of selective extermination. Australian Journal of Politics and History, 58, 159-180.

Bellamy, A. J. (2012b). Massacres and morality: Mass atrocities in an age of civilian immunity. Oxford: Oxford University Press.

Bellamy, A. J. (2015). Operationalizing the "atrocity prevention lens": Making prevention a living reality. In S. P. Rosenberg, T. Galis, \& A. Zucker (Eds.), Reconstructing atrocity prevention. Cambridge: Cambridge University Press.

Benesch, S. (2014). Countering dangerous speech to prevent mass violence in Kenya's 2013 elections. Retrieved from http://www.voicesthatpoison.org/ resources/countering-dangerous-speech-kenya2013

Boudon, R. (1989). The analysis of ideology. Cambridge: Polity Press.

Bratić, V. (2008). Examining peace-oriented media in areas of violent conflict. The International Communication Gazette, 70, 487-503.

Browning, C. R. (2001). Ordinary men: Reserve Police Battalion 101 and the final solution in Poland. London: Penguin Books.

Browning, C. R. (2004). The origins of the final solution: The evolution of Nazi Jewish policy. London: Arrow Books.

Burgess, S. (2011). The African Standby Force, genocide, and international relations theory. Genocide Studies and Prevention, 6, 121-133.

Caplan, R. (2011). Seeing the responsibility to protect in perspective. Ethnopolitics, 10, 129-132.

Ceadel, M. (1987). Thinking about peace and war. Oxford: Oxford University Press.

Chalk, F., \& Jonassohn, K. (1990). The history and sociology of genocide: Analyses and case studies. New Haven: Yale University Press.

Chandler, D. (2000). Voices from S-21: Terror and history in Pol Pot's secret prison. Chiang Mai: Silkworm Books.

Chirot, D., \& Mccauley, C. (2006). Why not kill them all?: The logic and prevention of mass political murder. Princeton: Princeton University Press.

Cigar, N. (1995). Genocide in Bosnia: The policy of "ethnic cleansing". College Station: Texas A\&M University Press.

Cohen, S. (2001). States of denial: Knowing about atrocities and suffering. Cambridge: Polity Press.

Collier, P., \& Vicente, P. C. (2013). Votes and violence: Evidence from a field experiment in Nigeria. The Economic Journal, 124, F327-F355.

De Waal, A., Meierhenrich, J. \& Conley-Zilkic, B. (2012). How mass atrocities end: An evidence-based counter-narrative. The Fletcher Forum of World Affairs, 36, 15-31.

Della Vigna, S., \& Gentzkow, M. (2010). Persuasion: Empirical evidence. Annual Review of Economics, 2, 643-669.

Drezner, D. W. (2011). Sanctions sometimes smart: targeted sanctions in theory and practice. International Studies Review, 13, 96-108.

Edelman, M. (1977). Political language: Words that succeed and policies that fail. New York: Academic Press.

Figes, O. (2002). The whisperers: Private life in Stalin's Russia. London: Penguin Books.

Finnemore, M, \& Sikkink, K. (1998). International norm dynamics and political change. International Organization, 52(4), 887-917.

Freeden, M. (1996). Ideologies and political theory: $A$ conceptual approach. Oxford: Oxford University Press.

Freeden, M. (2008). Thinking politically and thinking about politics: Language, interpretation, and ideology. In D. Leopold \& M. Stears (Eds.), Political theory: Methods and approaches. Oxford: Oxford University Press.

Fujii, L. A. (2004). Transforming the moral landscape: The diffusion of a genocidal norm in Rwanda. Journal of Genocide Research, 6, 99-114.

Fujii, L. A. (2008). The power of local ties: Popular participation in the Rwandan genocide. Security Studies, 17, 568-597.

Fujii, L. A. (2009). Killing neighbours: Webs of violence in Rwanda. Ithaca: Cornell University Press.

Gagnon, V. P. (2004). The myth of ethnic war: Serbia and Croatia in the 1990s. Ithaca: Cornell University Press.

Gardner, H. (2006). Changing minds: The art and science of changing our own and other people's minds. Boston, MA: Harvard Business School Press.

Gellately, R., \& Kiernan, B. (2003). Investigating genocide. In R. Gellately \& B. Kiernan (Eds.), The specter of genocide: Mass murder in historical perspective. Cambridge: Cambridge University Press.

Geniets, A. (2011). Trust in international news media in partially free media environments: A Case study of five markets in Africa and South Asia (Working Paper). Oxford: Reuters Institute for the Study of Journalism, University of Oxford. 
Gerlach, C. (2010). Extremely violent societies: Mass violence in the Twentieth-Century World. Cambridge: Cambridge University Press.

Gerring, J. (1997). Ideology: A definitional analysis. Political Research Quarterly, 50, 957-994.

Glaeser, E. (2005). The political economy of hatred. Quarterly Journal of Economics, 120, 45-86.

Goldhagen, D. (2010). Worse than war: genocide, eliminationism and the ongoing assault on humanity. London: Abacus.

Goldman, W. Z. (2011). Inventing the enemy: denunciation and terror in Stalin's Russia. Cambridge: Cambridge University Press.

Gordy, E. (1999). The culture of power in Serbia: nationalism and the destruction of alternatives. University Park: Pennsylvania State University Press.

Grace, R., \& Bruderlein, C. (2012). Building effective monitoring, reporting, and fact-finding mechanisms (Program on Humanitarian Policy and Conflict Research Draft Working Paper Series). Cambridge, MA: Harvard University.

Grebe, J. (2010). And they are still targeting: Assessing the effectiveness of targeted sanctions against Zimbabwe. Africa Spectrum, 45, 3-29.

Gregg, H. S. (2010). Fighting the Jihad of the Pen: Countering revolutionary Islam's ideology. Terrorism and Political Violence, 22, 292-314.

Hamilton, M. B. (1987). The elements of the concept of ideology. Political Studies, 35, 18-38.

Harff, B. (2003). No lessons learned from the holocaust? Assessing risks of genocide and political mass murder since 1955. American Political Science Review, 97, 57-73.

Hatzfield, J. (2005). A time for machetes. The Rwandan genocide: The killers speak. London: Serpent's Tail.

Hinton, A. L. (1998). Why did you kill?: The Cambodian genocide and the dark side of face and honour. The Journal of Asian Studies, 57, 93-122.

Hochschild, J. L. (2001). Where you stand depends on what you see: Connections among values, perceptions of fact, and political prescriptions. In J. H. Kuklinski (Ed.), Citizens and politics: Perspectives from political psychology. Cambridge: Cambridge University Press.

Hoess, R. (1959). Commandant of Auschwitz. London: Weidenfeld \& Nicholson.

Horgan, J., \& Braddock, K. (2010). Rehabilitating the terrorists? Challenges in assessing the effectiveness of de-radicalization programs. Terrorism and Political Violence, 22(2), 267-291.

Hufbauer, G., Schott, J., \& Elliot, K. (2007). Economic sanctions reconsidered. Washington, D.C.: Institute for International Economics.

Hultman, L. (2010). Keeping peace or spurring violence? Unintended effects of peace operations on violence against civilians. Civil Wars, 12, 29-46.
IPSOS MORI. (2014). Perceptions are not reality: Things the world gets wrong. Retrieved from https:// www.ipsos-mori.com/researchpublications/resea rcharchive/3466/Perceptions-are-not-realityThings-the-world-gets-wrong.aspx

Jackson, K. D. (1989). The ideology of total revolution. In K. D. Jackson (Ed.), Cambodia 1975-1978: Rendezvous with death. Princeton: Princeton University Press.

Jentleson, B. (2006). Coercive diplomacy: Scope and limits in the contemporary world (Policy Analysis Brief). Muscatine: The Stanley Foundation.

Jost, J. T. (2006). The end of the end of ideology. American Psychologist, 61, 651-670.

Jost, J. T., \& Major, B. (2001). The psychology of legitimacy: Emerging perspectives on ideology, justice and intergroup relations. Cambridge: Cambridge University Press.

Jost, J. T., Federico, C. M., \& Napier, J. (2013). Political ideologies and their social psychological functions. In M. Freeden, L. Tower Sargent, \& M. Stears (Eds.), The Oxford handbook of political ideologies. Oxford: Oxford University Press.

Kalyvas, S. N. (2006). The logic of violence in civil war. Cambridge: Cambridge University Press.

Kaufman, S. J. (2001). Modern hatreds: The symbolic politics of ethnic war. Ithaca: Cornell University Press.

Kaufman, S. J. (2006). Symbolic politics or rational choice: Testing theories of extreme ethnic violence. International Security, 30, 45-86.

Knight, K. (2006). Transformations in the concept of ideology in the twentieth century. American Political Science Review, 100, 619-626.

Kogen, L. (2013). Testing a media intervention in Kenya: Vioja Mahakamani, dangerous speech, and the Benesch guidelines. Philadelphia: Centre for Global Communication Studies.

Koonz, C. (2003). The Nazi conscience. Cambridge, MA: The Belknap Press of Harvard University Press.

Kopelev, L. (1977). No jail for thought. London: Secker \& Warburg.

Krain, M. (2005). International intervention and the severity of genocides and politicides. International Studies Quarterly, 49, 363-387.

Kurspahić, K. (2003). Prime time crime: Balkan media in war and peace. Washington, DC: United States Institute for Peace.

Leader Maynard, J. (2014). Rethinking the role of ideology in mass atrocities. Terrorism and Political Violence, 26, 821-841.

Leader Maynard, J. (2015). Combating atrocityjustifying ideologies. In S. K. Sharma \& J. M. Welsh (Eds.), The responsibility to prevent: Overcoming the challenges to atrocity prevention. Oxford: Oxford University Press.

Lopez, G. A. (2013). Enforcing human rights through 
economic sanctions. In D. Shelton (Ed.), The Oxford handbook of international human rights law. Oxford: Oxford University Press.

Lopez, G. A. (2015). Mobilizing economic sanctions for preventing mass atrocities: From targeting dictators to enablers. In S. P. Rosenberg, T. Galis, \& A. Zucker (Eds.), Reconstructing atrocity prevention. Cambridge: Cambridge University Press.

Lozowick, Y. (2000). Hitler's bureaucrats: The Nazi security police and the banality of evil. London: Continuum.

Malešević, S. (2006). Identity as ideology: Understanding ethnicity and nationalism. Basingstoke: Palgrave Macmillan.

Mann, M. (2000). Were the perpetrators of genocide "ordinary men" or "real nazis"? Results from fifteen hundred biographies. Holocaust and Genocide Studies, 14, 331-366.

Mann, M. (2005). The dark side of democracy: Explaining ethnic cleansing. Cambridge: Cambridge University Press.

McCauley, C., \& Moskalenko, S. (2008), Mechanisms of political radicalization: Pathways toward terrorism. Terrorism and Political Violence, 20(3), 415-433.

McChesney, R. W. (2004). The problem of the media. New York: Monthly Review Press.

McMahon, P. (2007). Taming ethnic hatred: Ethnic cooperation and transnational networks in Eastern Europe. Syracuse: Syracuse University Press.

Melander, E. (2009). Selected to go where murderers lurk? The preventive effect of peacekeeping on mass killings of civilians. Conflict Management and Peace Science, 26, 389-406.

Melson, R. (2003). Modern genocide in Rwanda: Ideology, revolution, war and mass murder in an African state. In R. Gellately \& B. Kiernan (Eds.), The specter of genocide: Mass murder in historical perspective. Cambridge: Cambridge University Press.

Metzl, J. F. (1997). Information intervention: When switching channels isn't enough. Foreign Affairs, 76, 15-20.

Michaelsen, C. (2010). The Security Council's Al Qaeda and Taliban sanctions regime: "Essential tool" or increasing liability for the UN's counterterrorism efforts? Studies in Conflict and Terrorism, 33, 448463.

Monroe, K. R. (2011). Ethics in an age of terror and genocide. Princeton: Princeton University Press.

Mueller, J. (2000). The banality of "ethnic war". International Security, 25, 42-70.

Noakes, J., \& Pridham, G. (1988). Nazism 1919-1945: A documentary reader. Exeter: University of Exeter Press.

Opotow, S. (1990). Moral exclusion and injustice: An introduction. Journal of Social Issues, 46, 1-20.

Paluck, E. L. (2009). Reducing intergorup prejudice and conflict using the media: A field experiment in
Rwanda. Journal of Personality and Social Psychology, 96, 574-587.

Paluck, E. L., \& Green, D. P. (2009). Deference, dissent, and dispute resolution: An experimental intervention using mass media to change norms and behavior in Rwanda. American Political Science Review, 103, 622-644.

Peskin, V. (2009). The International Criminal Court, the Security Council, and the politics of impunity in Darfur. Genocide Studies and Prevention, 4, 304238.

Power, S. (2003). "A problem from hell": America and the age of genocide. London: Flamingo.

Price, M. E. (2000). Information intervention: Bosnia, the Dayton Accords, and the seizure of broadcasting transmitters. Cornell International Law Journal, 33, 67-112.

Price, M. E., \& Thompson, M. (Eds.) (2002). Forging peace: Intervention, human rights and the management of media space. Bloomington: Indiana University Press.

Reike, R., Sharma, S. K., \& Welsh, J. M. (2015). Conceptualizing the responsibility to prevent. In S. K. Sharma \& J. M. Welsh (Eds.), The responsibility to prevent: Overcoming the challenges of atrocity prevention. Oxford: Oxford University Press.

Risse-Kappen, T., Ropp, S. C., \& Sikkink, K. (Eds.). (1999). The power of human rights: International norms and domestic change. Cambridge: Cambridge University Press.

Robinson, G. (2010). "If you leave us here, we will die": How genocide was stopped in East Timor. Princeton: Princeton University Press.

Sanín, F. G., \& Wood, E. J. (2014). Ideology in civil war: Instrumental adoption and beyond. Journal of Peace Research, 51, 213-226.

Schissler, M. (2014). Echo chambers in Myanmar: Social media and the ideological justifications for mass violence. Unpublished Manuscript.

Search For Common Ground. (2012). Search for Common Ground progress report 2012. Washington, DC/Brussels: Search for Common Ground.

Semelin, J. (1993). Unarmed against Hitler: Civilian resistance in Europe, 1939-1943. Westport, CN: Praeger.

Semelin, J. (2003). Analysis of a mass crime: Ethnic cleansing in the Former Yugoslavia, 1991-1999. In R. Gellately \& B. Kiernan (Eds.), The specter of genocide: Mass murder in historical perspective. Cambridge: Cambridge University Press.

Semelin, J. (2005). Purify and destroy: The political uses of massacre and genocide. London: Hurst \& Company.

Sewall, S., Raymond, D. \& Chin, S. (2010). MAROMass Atrocity Response Operations: A military planning handbook. Cambridge, MA: The President 
and Fellows of Harvard College.

Shabad, R. (2015). US has spent more than $\$ 3$ billion fighting ISIS. The Hill. Retrieved from http://thehill. com/policy/finance/249264-us-fight-against-isissurpasses-3-billion

Sharma, S. K. (2015). The 2007-8 post-election crisis in Kenya: A case of escalation prevention. In S. K. Sharma \& J. M. Welsh (Eds.), The responsibility to prevent: Overcoming the challenges of mass atrocity prevention. Oxford: Oxford University Press.

Shaw, M. (2003). War and genocide. Cambridge: Polity Press.

Sikkink, K. (2011). The justice cascade: How human rights prosecutions are changing world politics. New York: WW Norton \& Company.

Simon, D. (2012). Building state capacity to prevent atrocity crimes: Implementing pillars one and two of the R2P framework (Policy Analysis Brief). Muscatine: The Stanley Foundation.

Slim, H. (2007). Killing civilians: Method, madness and morality in war. London: Hurst \& Company.

Smeulers, A. (2008). Perpetrators of international crimes: Towards a typology. In A. Smeulers \& R. Haveman (Eds.), Supranational criminology: Towards a criminology of international crimes. Antwerpen: Intersentia.

Smith, A. M. (2012). The emergence of international justice as coercive diplomacy: Challenges and prospects (HRP Research Working Paper Series). Cambridge, MA: Harvard Law School.

Solonari, V. (2010). Purifying the nation: Population exchange and ethnic cleansing in Nazi-allied Romania. Washington, DC: Woodrow Wilson Center Press.

Straus, S. (2012a). "Destroy them to save us": Theories of genocide and the logics of political violence. Terrorism and Political Violence, 24, 544-560.

Straus, S. (2012b). Retreating from the brink: Theorizing mass violence and the dynamics of restraint. Perspectives on Politics, 10, 342-362.

Straus, S. (2015). Making and unmaking nations: War, leadership, and genocide in modern Africa. Ithaca: Cornell University Press.
Tardy, T. (2011). A critique of robust peacekeeping in contemporary peace operations. International Peacekeeping, 18, 152-167.

Thompson, R. L. (2011). Radicalization and the use of social media. Journal of Strategic Security, 4, 167190.

Thompson, M., \& Price, M. E. (2003). Intervention, media and human rights. Survival, 45, 183-202.

Tostensen, A., \& Bull, B. (2002). Are smart sanctions feasible? World Politics, 54, 373-403.

United Nations. (2014). Framework of analysis for atrocity crimes. New York: United Nations Office on Genocide Prevention and the Responsibility to Protect.

Valentino, B. A. (2004). Final solutions: Mass killing and genocide in the 20th Century. Ithaca: Cornell University Press.

Varki, A., \& Brower, D. (2013). Denial: self-deception, false beliefs and the origins of the human mind. New York, Twelve.

Waller, J. (2007). Becoming evil: How ordinary people commit genocide and mass killing. Oxford: Oxford University Press.

Weiss, T. G. (1999). Sanctions as a foreign policy tool: Weighing humanitarian impulses. Journal of Peace Research, 36, 499-509.

Weitz, E. D. (2003). A century of genocide: Utopias of race and nation. Princeton: Princeton University Press.

Welsh, J. M. (2015). Mediation and sanctions: applying conflict prevention tools in atrocity crime settings. In S. K. Sharma, \& J. M. Welsh (Eds.), The responsibility to prevent: Overcoming the challenges of mass atrocity prevention. Oxford: Oxford University Press.

Wolfsfeld, G. (2004). Media and the path to peace. Cambridge: Cambridge University Press.

Wood, R. M., Kathman, J. D., \& Gent, S. E. (2012). Armed intervention and civilian victimization in intrastate conflicts. Journal of Peace Research, 49(5), 647-660.

Yanagizawa-Drott, D. (2014). Propaganda and conflict: Evidence from the Rwandan genocide. The Quarterly Journal of Economics, 129, 1947-1994.

\section{About the Author}

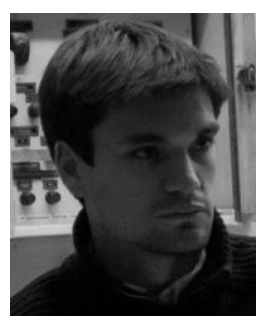

\section{Dr. Jonathan Leader Maynard}

Jonathan Leader Maynard is a Departmental Lecturer in International Relations in the Department of Politics and International Relations at the University of Oxford, and a Research Associate of the Oxford Institute for Ethics, Law and Armed Conflict. He works broadly on the role of ideology in political violence, particularly mass violence against civilians, from an interdisciplinary approach drawing on international relations, genocide studies, political and social psychology, and intellectual history. 